\title{
REVIEW
}

\section{Key Information Related to Quality by Design (QbD) Applications in Analytical Methods Development}

\author{
Alisson Silva Araújo1 (iD, Daniel Fernandes Andrade ${ }^{1}$ iD, Diego Victor Babos ${ }^{1}$ (D), Jeyne Pricylla \\ Castro $^{1}$ (D), José Augusto Garcia1 ${ }^{1}$, Marco Aurelio Sperança² ${ }^{\text {(D) }}$, Raimundo Rafael Gamela1 (iD, \\ Raquel Cardoso Machado' ${ }^{1}$, Vinícius Câmara Costa ${ }^{3}$ (D), Wesley Nascimento Guedes² (iD, \\ Edenir Rodrigues Pereira-Filho' ${ }^{1}$ and Fabíola Manhas Verbi Pereira ${ }^{2,4 *}$ iD \\ ${ }^{1}$ Grupo de Análise Instrumental Aplicada (GAIA), Departamento de Química, Universidade Federal de São Carlos \\ (UFSCar), 13565-905 São Carlos - SP, Brazil \\ ${ }^{2}$ Grupo de Abordagens Analíticas Alternativas (GAAA), Instituto de Pesquisa em Bioenergia (IPBEN), Instituto de \\ Química, Universidade Estadual Paulista (Unesp), 14800-060 Araraquara - SP, Brazil \\ ${ }^{3}$ Laboratório de Espectrometria Atômica (LEA)/LabPetro, Departamento de Química, Universidade Federal do \\ Espírito Santo (UFES), 29075-910 Vitória - ES, Brazil \\ ${ }^{4}$ Instituto Nacional de Tecnologias Alternativas para Detecção, Avaliação Toxicológica e Remoção de \\ Contaminantes Emergentes e Radioativos (INCT-DATREM), 14800-060 Araraquara - SP, Brazil
}

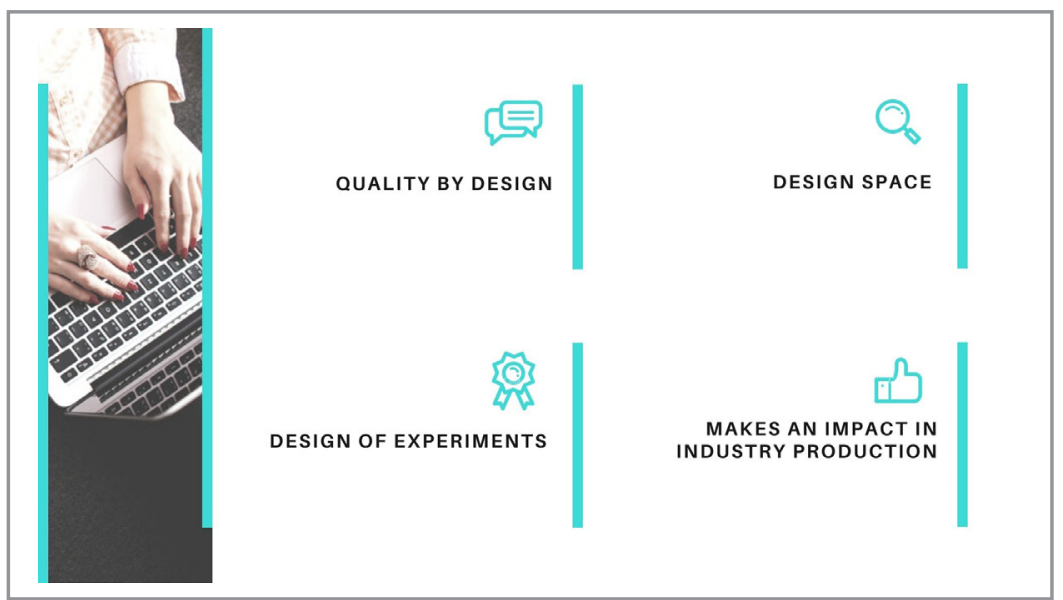

In this review, quality by design (QbD) initiatives are described as applications for many types of processes, such as in the pharmaceutical industry, biotechnology field, and for analytical methods development. Design space (DS) and design of experiments (DoE) provide useful results for analytical methods development and simulation of advanced processes in traditional manufacturing relationships. The three topics, QbD, DS and DoE are the best way to achieve strong and efficient industrial production.

Keywords: chemometrics, quality by design, control strategy, design of experiments, analytical chemistry in industrial applications

Cite: Araújo, A. S.; Andrade, D. F.; Babos, D. V.; Castro, J. P.; Garcia, J. A.; Sperança, M. A.; Gamela, R. R.; Machado, R. C.; Costa, V. C.; Guedes, W. N.; Pereira-Filho, E. R.; Pereira, F. M. V. Key Information Related to Quality by Design (QbD) Applications in Analytical Methods Development. Braz. J. Anal. Chem., 2021, 8 (30), pp 14-28. doi: http://dx.doi.org/10.30744/ brjac.2179-3425.RV-27-2020

Submitted 1 June 2020, Resubmitted 9 August 2020, $2^{\text {nd }}$ time Resubmitted 6 October 2020, Accepted 8 October 2020, Available online 20 October 2020. 
List of Selected Acronyms

\begin{tabular}{llll}
\hline Analytical quality by design & AQbD & Plackett-Burman & PB \\
\hline Box-Behnken design & BBD & Principal component analysis & PCA \\
\hline Capillary electrophoresis & CE & Process analytical technology & PAT \\
Central composite design & CCD & Quality by design & QbD \\
Coefficient of determination & $\mathrm{R}^{2}$ & Quality by testing & QbT \\
Critical method attributes & CMAs & Quality control & QC \\
Critical quality attributes & CQAs & Quality target product profiles & QTPPs \\
Design of experiments & DoE & Response surface methodology & RSM \\
\hline Design space or Design spaces & DS or DSs & Risk assessment & RA \\
\hline Fractional factorial design & FFD & United States Food and Drug Administration & US FDA \\
Method operational design region & MODR & United States Pharmacopeia & USP \\
\hline
\end{tabular}

\section{INTRODUCTION}

Quality by design $(\mathrm{QbD})$ approach has been extensively applied to pharmaceutical products development as can be observed by many applications in industry quality control, and research and development (R\&D) laboratories. When compared with quality by testing (QbT), QbD improves the understanding of processes and products with predefined goals based on statistical, mathematical, chemistry and quality risk management. There are four steps related to $\mathrm{QbD}$ processes:

1. Analytical target profile (ATP), which includes the purpose of an analytical method and its required performance criteria (critical quality attributes - CQAs);

2. Risk assessment. This step is related to sample preparation for further analytes determination, focuses on data analysis. Then, further potential variables as noise variables can be identified so, they are evaluated by measurement system analysis approaches, and instrumental parameters, which is assessed by design of experiment (DoE) strategies (a critical part);

3. From DoE results, the design space (DS) is obtained. DS shows the analytical chemistry conditions where an analytical method or production procedure can work without compromise the final result. This component is the establishment of reliable methods intended to be used in analytical chemistry laboratories;

4. Control strategy and validation are conducted via observation of several analytical figures of merit, such as accuracy and precision expressed as relative standard deviation (RSD) and coefficient of determination $\left(R^{2}\right)$, among others [1-4].

Pharmaceutical laboratories and companies have employed $\mathrm{QbD}$ to reach the excellence of their products. Drug efficacy and safety are key criteria to ensure pharmaceutical product quality. Thus, QbD initiatives are able to analyze factors that can compromise the stability of a drug. For example, Michels and coworkers [5] applied the QbD framework to develop and validate a capillary electrophoresis-sodium dodecyl sulfate assay using a laser-induced fluorescence detector for monitoring impurities from the manufacturing process of therapeutic monoclonal antibodies to ensure patient safety and product efficacy.

Since then, $\mathrm{QbD}$ was introduced to chemical manufacturing control (CMC), and this approach has gained popularity in the pharmaceutical manufacturing sector [6]. As mentioned before, $\mathrm{QbD}$ has been 
extensively useful in the pharmaceutical industry to understand drug quality parameters. Excipients, for example, are critical to drug performance, requiring a thorough interpretation of their chemical properties, composition and control of their variability to ensure high product quality.

Direct compression is an important attribute in the manufacturing of new tablets, and thus, it is necessary to know the properties of raw materials, as excipients, to ensure the effectiveness of large batch production. In addition, some properties of these materials are closely correlated, presenting interaction effects, so a multivariate analysis is mandatory to identify and relate these attributes to excipient performance [7].

An important mechanism that take several advantages of $\mathrm{QbD}$ is process analytical technology (PAT). Actually, PAT and QbD are aligned. PAT can be defined as a series of analytical control procedures and the manufacturing of new materials that are focused on the quality parameters of a target product. In the chemical industry, PAT concept has been used for some decades, in which process analyzers such as near infrared spectroscopy (NIRS) and nuclear magnetic resonance (NMR) are used to optimize productivity, as well as quality. The data generated by these analytical instrumental techniques are modeled by statistical and mathematical tools, such as principal component analysis (PCA) and partial least squares (PLS). Thus, due to these innovations of analytical instruments and the ability to model the data generated by these detection methods, PAT has been increasingly adopted by the pharmaceutical industry to assist in improving and modernizing the manufacturing of new drugs.

Nowadays, the implementation of PAT in the field of biotechnology has received special attention due to the complexities of the raw materials used in products development [8].

Covering all aspects described in the previous paragraphs, we must mention the Chemometric tools. Chemometrics is a science dedicated to perform a better visualization and interpretation from chemical data. This science has been barely used for optimization in electroanalytical applications when comparing to spectroscopy and chromatography methods $[9,10]$.

This review is intended to present some applications of $\mathrm{QbD}$ in pharmaceutical field as also, other promising areas. Chemometrics is "spread" in all text, turning QbD a powerful tool for variables optimization of chromatographic analytical methods allowing that experimental conditions achieve successful separation, identification and quantification of the target species.

DoE can be used for several applications depending on issue to be solved. In a review paper, Hibbert [11] described the use of several DoE processes applied to chromatographic separation and highlighted the most used in optimization and validation studies such as: (1) Factorial design [12-14]; (2) PlackettBurman (PB) design [15-17]; (3) Central Composite design (CCD) [18-20]; (4) Box-Behnken design (BBD) [21-23]; (5) Doehlert design (DD) [24-26] and (6) Mixture design [27-29]. Other types of DoE have been used and often cited in the literature, as examples Mixed-level fractional factorial design [30-32]; Definitive Screening design (DSD) [33-35] and D-optimal design [36-38].

The interest in $\mathrm{QbD}$ by industry and laboratories is increasing. Figure 1 shows the number of publications related to this topic since 1977 using Web of Science database. From 1977 to 2006, only 23 papers were published. It is possible to see the ever-increasing number of publications on this topic which in 2018 and 2019 more than 200 articles were published. 


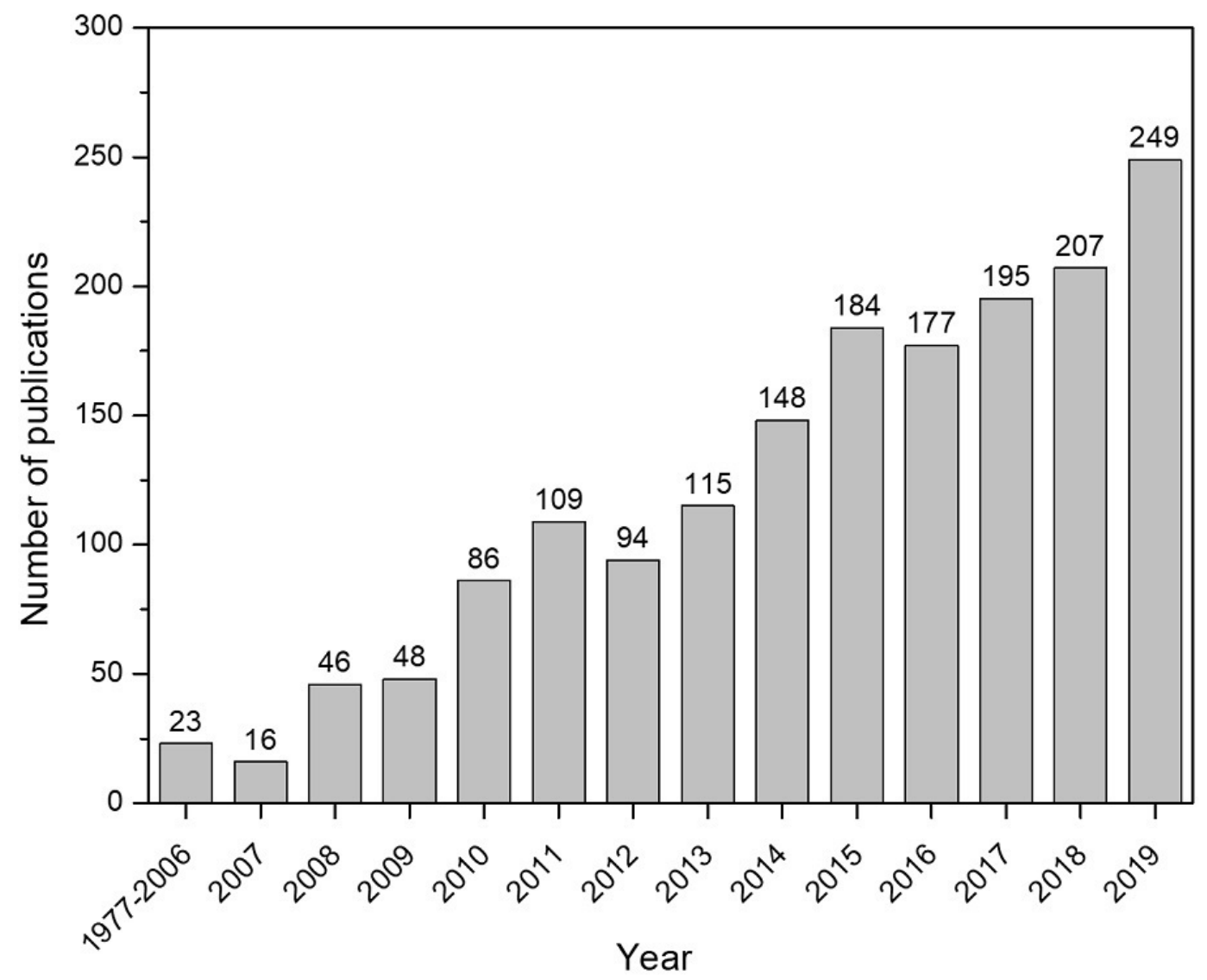

Figure 1. Publications related to quality by design (QbD) from 1977 to 2019.

The dataset used in this research was downloaded from the online database Science Citation Index Expanded (SCI-EXPANDED), and all documents types were considered. These results were exported from the Web of Science using 500 records at a time, file format in full record and cited references as well as tab-delimited (Win) for the file format. A bibliometric map for occurrence analysis of author keywords was obtained using the VOSviewer software (version 1.6.15; www.vosviewer.com). Figure 2 shows the top 50 author keywords with the highest co-occurrence among the 1,607 articles addressed to the keywords "analytical quality by design" OR "quality by design" on July 27,2020 . This bibliometric map shows a set of links connecting different research topics (i.e. clusters indicated in different colors) and how QbD can be associated with other important topics, such as DS, DoE, and PAT. Details explaining how this bibliometric analysis is prepared can be found in the following Youtube Playlist: https://www.youtube.com/ playlist?list=PL4CuftF4I_fCc9t1xoQSaYOUq-UBz_2VD 


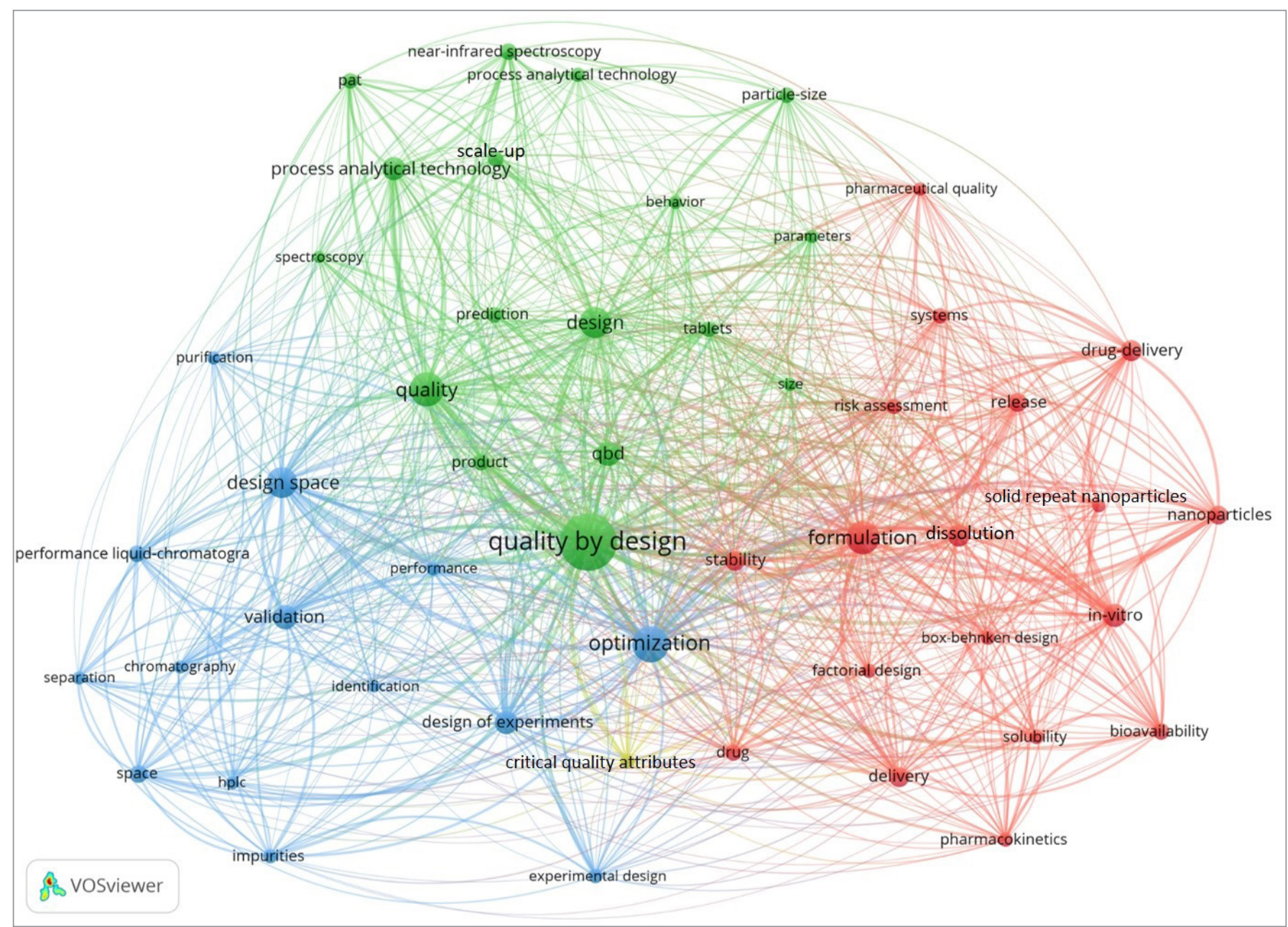

Figure 2. Bibliometric map for quality by design $(Q b D)$ relations with main important topics. Keywords used: "analytical quality by design" OR "quality by design". Number of words: 50 and more details about the bibliometric analysis can be found in the following Youtube Channel: https://www.youtube.com/c/EdenirPereiraFilho

This review aims to introduce the reader to this important topic and mainly, show how the scientific authors applied these concepts. The text addresses three complementary parts: QbD, DS and DoE and, Table I emphasizes recent applications.

\section{Quality by design (QbD), design of space and design of experiments applications}

In 2018, Dispas et al. [39] discussed the importance of QbD strategy for analyzing drug impurities. They mentioned that $\mathrm{QbD}$ facilitates quality risk management and provides ways to identify and control potential quality issues during both product development and manufacturing. It was also mentioned that one of the key challenges during the implementation of $\mathrm{QbD}$ strategies is the development of appropriate analytical methods to achieve the intended goals.

In 2017, a CE-based limit test for levomethorphan was developed. Critical method parameters were determined throughout scouting experiments and screened by FFD to establish the CQAs, which were optimized using Central composite face-centered design to define the method DS. The validation process was performed according to the International Council for Harmonisation of Technical Requirements for Pharmaceuticals for Human Use (ICH) guideline Q2 (R1) [40].

$A$ rapid colorimetric microplate bioassay for the estimation of bacitracin was proposed using $Q b D$ 
approach. For the optimization of the method, factorial design and response surface methodologies (RSM) were performed, and DS was established to ensure the method reproducibility [41].

Hashem and El-Sayed [42] proposed a new RP-HPLC method for the simultaneous determination of levetiracetam and pyridoxine $\mathrm{HCl}$ in prepared tablets using $\mathrm{QbD}$. Screening of four independent variables: $\mathrm{pH}$ of the mobile phase, flow rate, injection volume and percentage of the organic modifier at two levels, and optimization of the chromatographic variables were performed by FFD and CCD, respectively.

Tol et al. [43] developed a selective and robust HPLC method for separation of abacavir, lamivudine and dolutegravir (anti-retroviral formulation) in a drug product. QbD principles combined with a DoE were proposed to establish the relationship between critical response and tested variables.

QbD strategy was used by Mohamed et al. [44] to develop a new method combining vortex-aided salting-out-assisted liquid-liquid microextraction with a core-shell HPLC method establishing an efficient, sensitive and simultaneous determination of dorzolamide hydrochloride (DOR) and timolol maleate (TIM) in rabbit plasma with high analytical frequency. Screening of the knowledge space was performed with a PB design, and a BBD was applied for RSM.

Kozaki et al. [45] also studied the application of $\mathrm{QbD}$ to pharmaceutical development for analyzing critical process parameters (CPPs) of poly (lactic-co-glycolic acid) nanoparticle formulations encapsulating triamcinolone acetonide. CPPs were assessed by FFD and CCD, and then the results were visualized using RSM to identify DS.

In 2009, an overview of key developments and a roadmap regarding QbD principles for therapeutic biotechnology products was reported [46].

Terzić et al. [47] developed a specific and robust hydrophilic interaction liquid chromatography (HILIC) method for the determination of bilastine and its degradation impurities with high analytical frequency following analytical $\mathrm{QbD}(\mathrm{AQbD})$ strategy. Through the use of $\mathrm{BBD}$, a relationship between the CPPs and the CQAs was established, and further regression models and Monte Carlo simulations were used to identify the DS. Robustness testing was performed using FFD. In another study proposed by KasagicVujanović and Jancic-Stojanovic, the HILIC system was used for the determination of amitriptyline and its impurities as following substances, dibenzosuberone, cyclobenzaprine, nortriptyline and (5EZ,10RS)-5[3-(dimethylamino)propylidene-10,11-dihydro-5H-dibenzo[a,d][7]annulen-10-ol, and the same statistical treatment was applied [48].

Through QbD, Sylvester et al. [49] developed an HPLC method for the simultaneous determination of curcuminoids and doxorubicin from long-circulating liposomes. The authors established a MODR by means of a DoE and RSM. Within a linear range from 2 to $20 \mu \mathrm{g} / \mathrm{ml}$, and trueness between 97 to $104 \%$ were successfully achieved.

Sankar et al. [50] used QbD for determination of enzalutamide (ENZ), an atypical anticancer drug, in a drug formulation and in spiked plasma samples using UHPLC-electrospray ionization-tandem mass spectrometry (UHPLC-ESI-MS/MS). A DoE and CCD were used to screen and extensively evaluate the critical process attributes (CPAs), which can influence analytical parameters.

Another study using the $\mathrm{QbD}$ for method development of the estimation of quercetin dihydrate by HPLC was proposed by Sandhu et al. [51] FFD was used to screen the critical analytical attributes (CAAs), including the organic modifier, injection volume, column temperature and buffer strength. After that, the optimal conditions were determined through BBD and RSM, respectively.

Green analytical chemistry principles and $\mathrm{QbD}$ were applied to develop and validate the determination of fenoverine (FEN) in bulk and dosage form. In this study, a two-level FFD $\left(2^{7-3}\right)$ was applied to screening and identifying the influential chromatography method variables. Furthermore, the BBD was used to optimize the most important variables that actively affect the CAAs [52].

Mukthinuthalapati et al. [53] simultaneously determined antidiabetic drugs in their combined dosage forms employing HPLC. The effects of the variables, such as mobile phase composition, buffer strength, and flow rate were optimized using a BBD. Thus, the DoE and $\mathrm{QbD}$ allowed the separation of five analytes: metformin, pioglitazone, glibenclamide, glimepiride and repaglinide. 
In addition, Awotwe-Otoo et al. [54] used QbD to optimize a method based on the separation of hydrolyzed protamine sulfate peptides from a robust RP-HPLC method. Two experimental designs were used: (i) a PB design to evaluate main effect of the different variables, such as mobile phase $\mathrm{pH}$, flow rate of the mobile phase, injection volume, methanol concentration and column temperature, on peak resolution; and (ii) a three-level BBD with three center points to evaluate the principal, quadratic and interaction effects considering the column temperature, flow rate (on peak resolution), USP (United States Pharmacopeia) tailing and mobile phase $\mathrm{pH}$ (on the response), reducing the required number of experiments after optimization.

Dobricic et al. [55] used RP-HPLC for the simultaneous determination of telmisartan and impurities using $\mathrm{QbD}$. Variables including the acetonitrile (ACN) content in the first (ACN 1) and second (ACN 2) gradient steps were evaluated. In addition, time $\left(\mathrm{t}_{2}\right)$, the second gradient step and their combination affected the separation of telmisartan and its impurities.

QbD was also applied in bioanalytical method development for olmesartan medoxomil (OLM) determination in rat plasma using ultra-performance liquid chromatography (UPLC). For instance, Beg et al. [56] performed a $2^{5-2}$ FFD as a screening method to identify important variables and, posteriorly, to optimize them (mobile phase ratio and injection volume) using a CCD at three levels. BBD was also used for optimization of the extraction process conditions.

With the help of $\mathrm{QbD}$ concept, Sharma et al. [57] used a full factorial DoE $3^{3}$ to optimize the conditions of analyte separation for the determination of bambuterol. In another paper, Schmidt et al. [58] developed a method using DoE for the determination of impurities in the active pharmaceutical ingredient carbamazepine.

QbD was also applied to optimize lipid-polymer nanoparticles from a DoE at three levels of two critical independent variables, the lipidoid $5, L_{5}$ content and the L5:ASO ratio, for customizing luciferase gene transcription of antisense oligonucleotides (Luc-ASO) for delivery in HeLa pLuc/705 cells containing an aberrant luciferase gene [59].

Bade et al. [60] applied QbD using a DoE for optimization of the refolding process for a recombinant, biotech, therapeutic, granulocyte colony-stimulating factor. Risk analysis was performed to identify variables that required more attention. Afterwards, the chosen parameters were evaluated using an FFD.

$\mathrm{QbD}$ and PAT were used to investigate particle characterization during in-line, high-shear, wet granulation (HSWG) using focused beam reflectance measurement (FBRM). The optimizations were conducted from a DoE with nine scale-up levels developed in batches and eight clinical sublots using an FBRM probe to assess the variables and improve the process of development of this drug product [61].

A study using the $\mathrm{QbD}$ was applied in the production of a pharmaceutical gel. The quality target product profiles (QTPPs) were obtained from reference values of the previously batches. The critical variables of the process (viscosity and $\mathrm{pH}$ ) were optimized using a DoE that comprised 13 gel with triplicates at the center point. Afterwards, the best synergism values from the optimization of the QTPPs were defined using a desirability function [62].

Pasquini et al. [63] used a DoE to optimize the experimental parameters and variables from an electrokinetic method following QbD. From the optimization, a DS was defined, and the developed method was dedicated to quantify three antimigraine drugs in different pharmaceutical products available on the market.

Design of Experiments (DoE) is a statistical technique for screening of factors, planning, conducting, analyzing, optimizing the conditions of the system to be used and interpreting data from experiments. For $\mathrm{QbD}$, the use of DoE includes advantages as not requiring detailed knowledge of the system, definition of the number of experiments to be performed, and data modelling for empirical functions that are generally linear or quadratic $[11,64]$.

$\mathrm{QbD}$ concepts are normally used to analytical method development. Its use is increasing based on predefined requirements for an analytical method stated in the ATP. From this perspective, a DoE is mandatory to visualize the influence of the variables and its interactions on responses. For variable screening studies, the two-level full factorial design is the most widely used. Afterwards, variable screening 
and multilevel designs are generally considered for the efficient exploration of response functions from empirical models. The critical conditions of factors as maximum or minimum values are determined by RSM. Among these, the most used are the CCD, BBD, and DD $[11,65,66]$.

Ferreira et al. [10] reported an overview of most common factorial design methods for the optimization of sample preparation procedures and experimental conditions of analytical instrumental techniques dedicated to determination of organic and inorganic analytes in food. According to the authors, CCD is the most commonly used method, although it has a lower efficiency than DD or BBD. They also conclude that there is a high frequent use of chemometric tools for the optimization of analytical methods.

For instance, a DoE and RSM were used to optimize the process of biodiesel production using different types of catalysts (homogeneous and heterogeneous and acid) [67].

Wu et al. [68] proposed the Generalized Multiplicative ANOVA (GEMANOVA) model as an alternative to ANOVA (analysis of variance) for improving the interpretation and understanding of complex data sets obtained from monitoring the physical stability of a solid dispersion with X-ray powder diffraction (XRPD). The results obtained by the GEMANOVA model were easier to interpret and understand than those obtained from the ANOVA model, and a DS was established according to the QbD. Table I shows some selected papers and its remarks about QbD application in Pharmaceutical industry, Industrial purposes and Optimization using DoE.

Table I. Selected papers of applying QbD principles to common scientific fields

\begin{tabular}{|c|c|c|}
\hline Field & Remark & References \\
\hline $\begin{array}{l}\text { Pharmaceutical } \\
\text { industry }\end{array}$ & $\begin{array}{l}\text { - Chromatographic methods for separation, identification and } \\
\text { determination } \\
\text { - Starting materials and reagents evaluation in manufacturing } \\
\text { - Identification of unexpected impurities } \\
\text { - Granulation and tableting processes } \\
\text { - Dosage form of a solid inhaled drug }\end{array}$ & [69-86] \\
\hline Industrial purposes & $\begin{array}{l}\text { - Development and optimization a chitosan film formulation } \\
\text { - Identification of stable and robust microemulsions } \\
\text { - Evaluation of the kinetics of a powder mixing process } \\
\text { - QbD to assess the subfractions of lipoprotein }\end{array}$ & [87-95] \\
\hline $\begin{array}{l}\text { Optimization tools } \\
\text { using DoE }\end{array}$ & $\begin{array}{l}\text { - Nanoprecipitation (NPR) and nanospray drying (NSD) } \\
\text { application } \\
\text { - Optimization of cell culture parameters } \\
\text { - Determination, development and improvement of analytical } \\
\text { methods } \\
\text { - Selection of relevant variables in a system }\end{array}$ & [96-108] \\
\hline
\end{tabular}

DoEs have been used in these biotechnological processes for some years, as reported by Mandenius et al. [109] in a review paper, in which DoEs are a powerful tool for the optimization of bioprocesses.

$\mathrm{QbD}$ has been shown as a relevant scientific tool for developing efficient and safe medicinal products, as well as for reducing costs in the development of these products in health care industries [110].

DoE and RSM are critical tools for QbD implementation. Therefore, to comply with the established guidelines (ICH Q1, Q2 and Q3), studies have reported the importance of these tools to achieve successful results regarding the implementation of $\mathrm{QbD}$. Bezerra et al. [111] outlined a tutorial review about simplex optimization. This particular approach does not need complex mathematical and statistical tools to be performed and, consequently can be easily implemented. Another important study, from Ferreira et al. [112] 
is a review about the most known experimental designs, such as the BBD, DD, and the CCD. In addition, a tutorial entitled "Application of free computational program in experimental design: a tutorial" [113] makes DoE, one of the tools discussed in this review, accessible for any analyst or industry professional.

A fast HPLC screening method for the separation of eight antidiabetic compounds: pioglitazone (PZ), rosiglitazone (RZ), glyburide (GB), glimepiride (GM), gliquidone (GQ), gliclazide (GL), glipizide (GP), and repaglinide (RG), was proposed by Mokhtar et al. [114]. DS was developed using an in silico simulation of practical robustness testing procedures. The DS was calculated using a full two-level DoE for three different stationary phases varying buffer $\mathrm{pH}$, gradient elution parameters, and ternary solvent ratio. Furthermore, the method offered a fast separation (less than $6 \mathrm{~min}$ ) of the analytes that achieved the required levels of the CQAs.

Following the QbD principles, Schmidt et al. [115] defined a DS for a chromatographic method for the purity testing of pramipexole. Influential separation parameters were identified and assessed experimentally in a DoE $\left(3^{6}=729\right.$ experiments were performed in silico).

A DS was used by Arai et al. [116] in the granulation process of mefenamic acid tablets. Bootstrap resampling technique was used to evaluate robustness of the procedure. This procedure is used when predictions estimated by the quadratic polynomial model present unsatisfactory results in complex nonlinear problems. Thus, the Bootstrap resampling method is applicable to verify the accuracy of a nonlinear response surface.

DS and QbD concepts were implemented to evaluate the CPPs in ICH, Q8 R2, Q9 and Q10 for analytical method development and optimization of three chiral compounds. These compounds were developed as modulators of small conductance calcium-activated potassium (SK) channels using HPLC [117]. A DoEDS and CCD were used to investigate the effects of trifluoroacetic acid (TFA) and n-hexane concentration in an acetonitrile mobile phase for enantiomeric separation.

In the pharmaceutical field, the DS and DoE concepts are being increasingly used to optimize analytical methods. For instance, Jambo et al. [118] evaluated the use of mass spectrometric detection supercritical fluid chromatography (SFC-MS) to identify adulteration in medicinal cannabis plants. In order to optimize this method, DoE and DS approaches were applied. Kurmi et al. [119] also used a DoE to optimize the forced degradation conditions of furosemide acid.

In the study by Maeda et al. [120], QbD was used to build a more reliable large-scale $\mathrm{D}$. The experimental model system selected to construct the DS was the lubrication process for theophylline tablet manufacturing.

Mokhtar et al. [121] proposed a method to ensure more confidence in the produced DS regarding the robustness in compliance with ICH Q2 (R1). In this sense, a new DS calculation was developed that was compared to the conventional calculation. For this, a HPLC instrument was used and, with the assistance of a DoE, this DS mapped by the in silico robustness simulation provided more compliance to ICH Q2 (R1) than the previous alternatives.

A quantitative structure-retention relationship-design-of-experiment (QSRR-DoE) protocol to propose an optimal DS in a QbD procedure to improve HILIC method development in the separation of pharmaceutical targets was proposed by Taraji et al. [122]. A CCD for three selected chromatographic variables: acetonitrile concentration, mobile-phase $\mathrm{pH}$ and salt concentration, was used to model the retention times of a mixture of pharmaceutical analytes in HILIC. A QSRR model was generated and used to predict the retention time and, consequently, the selectivity variable between new target analytes.

Chhatre et al. [123] provided an important discussion about the combination of $\mathrm{QbD}$ and biochemical engineering to enable an efficient bioprocess development and manufacturing. The highlights of the main steps of QbD: risk assessment, statistical experimental design, scale-down techniques, rapid assays and graphical representation methods.

A study using $\mathrm{QbD}$ and a DS to develop a bioassay for the relative potency of linezolid in pharmaceutical samples was proposed by Saviano et al. [124]. DoE and CCD were applied to evaluate the influence of inoculum concentration and triphenyltetrazolium chloride on microbial growth. 
In 2017, Kormány et al. [125] proposed a generic workflow to compare the resolution of a pharmacopeia impurity profiling method in a large DS of 3 measured and 3 calculated variables. A modern LC modeling software (Drylab) was used for comparing critical variables in relation of different parts of the DS. The results showed that it is possible to interchange two columns and map the retention behavior of the compounds of interest in a small number of steps in an experimental study.

Sun et al. [126] combined a computer simulation program and a design of experiments statistical software to develop a multicomponent analytical determination method using HPLC, combining two detectors, a diode-array detector (DAD) and an evaporative light scattering detector (ELSD), connected in series. DoE was applied to in the workflow steps to minimize experimental risk variables and provide an efficient DS method.

Nadella et al. [127] used a DoE by applying QbD to identify a DS for determination of teriflunomide by a UPLC method in the presence of degradation products. A CCD was performed to evaluate the variables: resolution, retention time and peak tailing. The proposed method presented high analytical frequency.

\section{CONCLUSION AND PERSPECTIVE}

This review shows that traditional manufacturing relationships have been changing by $Q b D$. These methods are part of analytical quality improvements and mainly, aid to save energy and time. In addition, most methods described here are related to pharmaceutical purposes, but it was possible to verify the first steps in other areas. It is worthy to reinforce the importance of the design tools $(Q b D$, DS and DoE) and that they would be able to enhance other industrial processes. From the practical point of view, there is enough room for other applications in different fields of chemical industry.

\section{Acknowledgments}

This study was supported by the São Paulo Research Foundation (FAPESP) [grant numbers 2019/24223-5, 2018/18212-8, 2019/01102-8 and 2014/50945-4], the National Council for Scientific and Technological Development (CNPq) [grant numbers 307328/2019-8 and 465571/2014-0], the Coordination for the Improvement of Higher Education Personnel (CAPES) - Finance Code 001 [grant number $88887136426 / 2017 / 00]$.

\section{REFERENCES}

1. Rozet, E.; Lebrun, P.; Debrus, B.; Boulanger, B.; Hubert, P. TrAC, Trends Anal. Chem., 2013, 42, pp 157-167 (http://dx.doi.org/10.1016/j.trac.2012.09.007).

2. Deidda, R.; Orlandini, S.; Hubert, P.; Hubert, C. J. Pharm. Biomed. Anal., 2018, 161, pp 110-121 (https://doi.org/10.1016/j.jpba.2018.07.050).

3. Fukuda, I. M.; Pinto, C. F. F.; Moreira, C. D. S.; Saviano, A. M.; Lourenço, F. R. Braz. J. Pharm. Sci., 2018, 54, pp 1-16 (http://dx.doi.org/10.1590/s2175-97902018000001006).

4. Orlandini, S.; Pinzauti, S.; Furlanetto, S. Anal. Bioanal. Chem., 2013, 405, pp $443-450$ (https://doi. org/10.1007/s00216-012-6302-2).

5. Michels, D. A.; Parker, M.; Salas-Solano, O. Electrophoresis, 2012, 33 (5), pp 815-826 (https://doi. org/10.1002/elps.201100528).

6. Yu, L. X.; Amidon, G.; Khan, M. A.; Hoag, S. W.; Polli J.; Raju, G. K.; Woodcock, J. The AAPS Journal, 2014, 16 (4), pp 771-783 (https://doi.org/10.1208/s12248-014-9598-3).

7. Thoorens, G.; Krier, F.; Leclercq, B.; Carlin, B.; Evrard, B. Int. J. Pharm., 2014, 473, pp 64-72 (http:// dx.doi.org/10.1016/j.ijpharm.2014.06.055).

8. Rathore, A. S.; Bhambure, R.; Ghare, V. Anal. Bioanal. Chem., 2010, 398, pp 137-154 (https://doi. org/10.1007/s00216-010-3781-x).

9. Tarley, C. R. T.; Silveira, G.; dos Santos, W. N. L.; Matos, G. D.; da Silva, E. G. P.; Bezerra, M. A.; Miró, M.; Ferreira, S. L. C. Microchem. J., 2009, 92 (1), pp 58-67 (http://dx.doi.org/10.1016/j.microc.2009.02.002). 
10. Ferreira, S. L. C.; Silva Junior, M. M.; Felix, C. S. A.; Silva, D. L. F.; Santos, A. S.; Santos Neto, J. H.; Souza, C.T.; Cruz Junior, R. A.; Souza, A.S. Food Chem., 2019, 273, pp 3-8 (https://doi.org/10.1016/j. foodchem.2017.11.114).

11. Hibbert, D. B. J. Chromatogr. B, 2012, 910, pp 2-13 (http://dx.doi.org/10.1016/j.jchromb.2012.01.020).

12. Vdovenko, M. M.; Demiyanova, A. S.; Chemleva, T. A.; Sakharov, I. Y. Talanta, 2012, 94, pp 223-226 (https://doi.org/10.1016/j.talanta.2012.03.025).

13. Araújo, J. E.; Oliveira, E.; Otero-Glez, A.; Nores, J. S.; Igrejas, G.; Lodeiro, C.; Capelo, J. L.; Santos, H. M. Talanta, 2014, 119, pp 90-97 (http://dx.doi.org/10.1016/j.talanta.2013.10.019).

14. Lima, D. C.; Guedes, W. N.; Costa, V. C.; Amorim, F. A. C. J. Braz. Chem. Soc., 2018, 29 (9), pp 18851893 (http://dx.doi.org/10.21577/0103-5053.20180064).

15. Dejaegher, B.; Dumarey, M.; Capron, X.; Bloomfield, M. S.; Vander Heyden, Y. Anal. Chim. Acta., 2007, 595, pp 59-71 (https://doi.org/10.1016/j.aca.2006.11.077).

16. Olivieri,A. C.; Magallanes, J. F. Talanta, 2012, 97, pp242-248(https://doi.org/10.1016/j.talanta.2012.04.025).

17. Callao, M. P. TrAC, Trends Anal. Chem., 2014, 62, pp 86-92 (https://doi.org/10.1016/j.trac.2014.07.009).

18. Gustavo González, A.; González-Arjona, D. Talanta, 1999, 49, pp 433-439 (https://doi.org/10.1016/ S0039-9140(99)00005-3).

19. Djoudi, W.; Aissani-Benissad, F.; Bourouina-Bacha, S. Chem. Eng. J., 2007, 133, pp 1-6 (https://doi. org/10.1016/j.cej.2007.01.033).

20. Li, J.; Wang, H.; Li, H.; Xu, L.; Guo, Y.; Lu, F.; Pan, W.; Li, S. Int. J. Pharm., 2016, 498, pp 32-39 (https://doi.org/10.1016/j.jpharm.2015.12.005).

21. Ferreira, S. L. C.; Bruns, R. E.; Ferreira, H. S.; Matos, G. D.; David, J. M.; Brandão, G. C.; Silva, E. G. P.; Portugal, L. A.; Reis, O. S.; Souza, A. S., et al. Anal. Chim. Acta, 2007, 597, pp 179-186 (https:// doi.org/10.1016/j.aca.2007.07.011).

22. Amorim, F. A. C.; Costa, V. C.; Guedes, W. N.; Sá, I. P.; Santos, M. C.; Silva, E. G. P.; Lima, D. C. Food Anal. Methods, 2016, 9, pp 1719-1725 (https://doi.org/10.1007/s12161-015-0296-2).

23. Costa, V. C.; Guedes, W. N.; Santos, A. S.; Nascimento, M. M. Food Anal. Methods, 2018, 11, pp 2004-2012 (https://doi.org/10.1007/s12161-018-1171-8).

24. Hellal, F.;Dachraoui,M. Talanta, 2004,63(4),pp1089-1094(https://doi.org/10.1016/j.talanta.2004.01.011).

25. Reboucas, M. V.; Santos, J. B.; Pimentel, M. F.; Teixeira, L. S. G. Chemom. Intell. Lab. Syst., 2011, 107 (1), pp 185-193 (https://doi.org/10.1016/j.chemolab.2011.03.007).

26. Silva, D. S.; dos Santos, C. S.; Pando, L. A.; Gomes, M. S. R.; Novaes, C. G.; Dos Santos, W. N. L.; Bezerra, M. A. Food Chem., 2019, 273, pp 71-76 (https://doi.org/10.1016/j.foodchem.2018.02.049).

27. Ferreira-Nunes, R.; Gratieri, T.; Gelfuso, G. M.; Cunha-Filho, M. J. Pharm. Biomed. Anal., 2018, 149, pp 612-617 (https://doi.org/10.1016/j.jpba.2017.11.069).

28. Li, N.; Shi, C.; Zhang, Z.; Wang, H.; Liu, Y. Compos. Part B Eng., 2019, 178, pp 1-14 (https://doi. org/10.1016/j.compositesb.2019.107490).

29. Bezerra, M. A.; Lemos, V. A.; Novaes, C. G.; de Jesus, R. M.; Souza-Filho, H. R.; Araújo, A. S.; Alves, J. P. S. Microchem. J., 2020, 152, pp 1-13 (https://doi.org/10.1016/j.microc.2019.104336).

30. Ai, M.; Yang, G.; Zhang, R. J. Stat. Plan. Inference., 2006, 136 (4), pp 1493-1511 (https://doi. org/10.1016/j.jspi.2004.10.001).

31. Pistone, G.; Rogantin, M. P. J. Stat. Plan. Inference., 2008, 138 (3), pp 787-802 (https://doi. org/10.1016/j.jspi.2007.02.007).

32. Han, X.; Liu, M. Q.; Yang, J. F.; Zhao, S. J. Stat. Plan. Inference., 2020, 204, pp 206-216 (https://doi. org/10.1016/j.jspi.2019.04.012).

33. Libbrecht, W.; Deruyck, F.; Poelman, H.; Verberckmoes, A.; Thybaut, J.; Clercq, J. D.; Voort, P. V. D. Chem. Eng. J., 2015, 259, pp 126-134 (https://doi.org/10.1016/j.cej.2014.07.113).

34. Gabbay, R. S.; Kenett, R. S.; Scaffaro, R.; Rubinstein, A. Eur. J. Pharm. Sci., 2018, 125, pp 102-109 (https://doi.org/10.1016/j.ejps.2018.09.020). 
35. Pereira, A. C.; Reis, M. S.; Leça, J. M.; Rodrigues, P. M.; Marques, J. C. Chemom. Intell. Lab. Syst., 2018, 179, pp 73-81 (https://doi.org/10.1016/j.chemolab.2018.06.010).

36. Harman, R.; Pronzato, L. Stat. Probab. Lett., 2007, 77(1), pp 90-94 (https://doi.org/10.1016/j.spl.2006.05.014).

37. Khaw, K. W.; Chew, X.; Yeong, W. C.; Lim, S. L. Chemom. Intell. Lab. Syst., 2019, 186, pp 33-40 (https://doi.org/10.1016/j.chemolab.2019.02.001).

38. Abdel-Raoof, A. M.; Said R. A. M.; Emara, M. S.; El-Desouky, E. A.; Abdelzaher, A. M.; Hasan, M. A.; Osman, A. E. Spectrochim. Acta-Part A, 2020, 235, pp 1-7 (https://doi.org/10.1016/j.saa.2020.118313).

39. Dispas, A.; Avohou, H. T.; Lebrun, P.; Hubert, P.; Hubert, C. TrAC, Trends Anal. Chem., 2018, 101, pp 24-33 (https://doi.org/10.1016/j.trac.2017.10.028).

40. Krait, S.; Heuermann, M.; Scriba, G. K. E. J. Sep. Sci., 2018, 41, pp 1405-1413 (https://doi.org/10.1002/ jssc.201701166).

41. Francisco, F. L.; Saviano, A. M.; Pinto, T. J. A.; Lourenço, F. R. Curr. Anal. Chem., 2016, 12, pp 620 627 (https://doi.org/10.2174/15734110126661601122304 07).

42. Hashem,H.;El-Sayed, H.M. Microchem. J., 2018, 143,pp55-63(https://doi.org/10.1016/j.microc.2018.07.031).

43. Tol, T.; Kadam, N.; Raotole, N.; Desai, A.; Samanta, G. J. Chromatogr. A, 2016, 1432, pp 26-38 (http://dx.doi.org/10.1016/j.chroma.2015.12.080).

44. Mohamed, A. M. I.; Abdel-Wadood, H. M.; Mousa, H. S. New J. Chem., 2016, 40, pp 8424-8437 (https://doi.org/10.1039/C5NJ03719K).

45. Kozaki, M.; Kobayashi, S. I.; Goda, Y.; Okuda, H.; Sakai-Kato, K. Chem. Pharm. Bull., 2017, 65, pp 218-228 (https://doi.org/10.1248/cpb.c16-00415).

46. Rathore, A. S. TrAC, Trends in Biotechnol., 2009, 27 (9), pp 546-553 (https://doi.org/10.1016/j. tibtech.2009.06.006).

47. Terzić, J.; Popović, I.; Stajić, A.; Tumpa, A.; Jančić-Stojanović, B. J. Pharm. Biomed., 2016, 125, pp 385-393 (http://dx.doi.org/10.1016/j.jpba.2016.04.022).

48. Kasagić-Vujanović, I.; Jančić-Stojanović, B. J. Pharm. Biomed., 2019, 173, pp $86-95$ (https://doi. org/10.1016/j.jpba.2019.05.026).

49. Sylvester, B.; Tefas, L.; Vlase, L.; Tomuta, I.; Porfire, A. J. Pharm. Biomed., 2018, 158, pp 395-404 (https://doi.org/10.1016/j.jpba.2018.06.018).

50. Sankar, A.; Palani, S.; Velayudham, R. Anal. Chem. Insights, 2017, 12, pp 1-11 (https://doi. org/10.1177/1177390117726776).

51. Sandhu, P. S.; Beg, S.; Kumar, R.; Katare, O. P.; Singh, B. J. Liq. Chromatogr. Relat. Technol., 2017, 40 (10), pp 506-516 (https://doi.org/10.1080/10826076.2017.1329744).

52. Saroj, S.; Jairaj, V.; Rathod, R. J. Liq. Chromatogr. Relat. Technol., 2017, 40 (7), pp $340-352$ (http:// dx.doi.org/10.1080/10826076.2017.1304414).

53. Mukthinuthalapati, M. A.; Bukkapatnam, V.; Kallepalli, P. J. Chromatogr. Sci., 2019, 57 (4), pp 339-348 (https://doi.org/10.1093/chromsci/bmz003).

54. Awotwe-Otoo, D.; Agarabi, C.; Faustino, P. J.; Habib, M. J.; Lee, S.; Khan, M. A.; Shaha, R. B. J. Pharm. Biomed. Anal., 2012, 62, pp 61-67 (https://doi.org/10.1016/j.jpba.2012.01.002).

55. Dobricic, V.; Vukadinovic, D.; JancicStojanovic, B.; Vladimirov, S.; Cudina, O. Chromatographia, 2017, 80, pp 1199-1209 (https://doi.org/10.1007/s10337-017-3330-2).

56. Beg, S.; Jainb, A.; Kaur, R.; Panda, S. S.; Katare, O. P.; Singh, B. J. Liq. Chromatogr. Relat. Technol., 2016, 39 (13), pp 587-597 (http://dx.doi.org/10.1080/10826076.2016.1206023).

57. Sharma, R.; Kamboj, S.; Khurana, R.; Singh, G.; Rana, V. Carbohyd. Polym., 2015, 134, pp 364-374 (http://dx.doi.org/10.1016/j.carbpol.2015.07.073).

58. Schmidt, A. H.; Stanic, M.; Molnár, I. J. Pharm. Biomed. Anal., 2014, 91, pp 97-107 (http://dx.doi. org/10.1016/j.jpba.2013.12.023).

59. Thanki, K.; Papai, S.; Lokras, A.; Rose, F.; Falkenberg, E.; Franzyk, H.; Foged, C. Pharm Res., 2019, 36, pp 1-15 (https://doi.org/10.1007/s11095-018-2566-3). 
60. Bade, P. D.; Kotu, S. P.; Rathore, A. S. J. Sep. Sci., 2012, 35, pp 3160-3169 (https://doi.org/10.1002/ jssc.201200476).

61. Huang, J.; Kaul, G.; Utz, J.; Hernandez, P.; Wong, V.; Bradley, D.; Nagi, A.; O’Grady, D. J. Pharm. Sci., 2010, 99 (7), pp 3205-3212 (https://doi.org/10.1002/jps.22089).

62. Rosas, J. G.; Blanco, M.; Alez, J. M. G. J. Pharm. Sci., 2011, 100, pp $4432-4441$ (https://doi. org/10.1002/jps.22611).

63. Pasquini, B.; Orlandini, S.; Bubba, M. D.; Bertol, E.; Furlanetto, S. Electrophoresis, 2015, 36, pp 26502657 (https://doi.org/10.1002/elps.201400472).

64. Grangeia, H. B.; Silva, C.; Simões, S. P.; Reis, M. S. Eur. J. Pharm. Biopharm., 2020, 147, pp 19-37 (https://doi.org/10.1016/j.ejpb.2019.12.007).

65. Ferreira, S. L. C.; Korn, M. G. A.; Ferreira, H. S.; Silva, E. G. P.; Araújo, R. G. O.; Souza, A. S.; Macedo, S. M.; Lima, D. C.; Jesus, R. M.; Amorim, F. A. C.; Bosque-Sendra, J. M. Appl. Spectrosc. Rev., 2007, 42, pp 475-491 (https://doi.org/10.1080/05704920701551506).

66. Ferreira, S. L. C.; Lemos, V. A.; Carvalho, V. S.; Silva, E. G. P.; Queiroz, A. F. S.; Felix, C. S. A.; Silva, D. L. F.; Dourado, G. B.; Oliveira, R. V. Microchem. J., 2018, 140, pp 176-182 (https://doi. org/10.1016/j.microc.2018.04.002).

67. Vicente, G.; Coteron, A.; Martinez, M.; Aracil, J. Ind. Crops. Prod., 1998, 8, pp $29-35$ (https://doi. org/10.1016/S0926-6690(97)10003-6).

68. Wu, J. X.; Berg, F. V. D.; Søgaard, S. V.; Rantanen, J. J. Pharm. Sci., 2013, 102, pp 904-914 (https:// doi.org/10.1002/jps.23409).

69. Debrus, B.; Guillarme, D.; Rudaz, S. J. Pharm. Biomed., 2013, 84, pp 215-223 (http://dx.doi. org/10.1016/j.jpba.2013.06.013).

70. Talluri, M. V.; Kalariya, P. D.; Dharavath, S.; Shaikh, N.; Garg, P.; Ramisetti, N. R.; Ragampeta, S. J. Sep. Sci., 2016, 39 (18), pp 3528-3535 (https://doi.org/10.1002/jssc.201501405).

71. Mohammed, A. Q.; Sunkari, P. K.; Mohammed, A. B.; Srinivas, P.; Roy, A. K. Org. Process. Res. Dev., 2015, 19 (11), pp 1645-1654 (https://doi.org/10.1021/op500297g).

72. Krait, S.; Scriba, G. K. E. Electrophoresis, 2018, 39 (20), pp 2575-2580 (https://doi.org/10.1002/ elps.201800100).

73. Garg, L. K.; Reddy, V. S.; Sait, S. S.; Krishnamurthy, T.; Vali, S. J.; Reddy, A. M. Chromatographia, 2013, 76, pp 1697-1706 (https://doi.org/10.1007/s10337-013-2509-4).

74. Shakya, A. K. Orient. J. Chem., 2016, 32 (2), pp 777-788 (http://dx.doi.org/10.13005/ojc/320203).

75. Petrusevska, V.; Krtalic, I.; Rasic, A.; Mornar. A. Anal. Methods, 2019, 11, pp 1777-1787 (https://doi. org/10.1039/C9AY00117D).

76. Yang, S. H.; Wang, J.; Zhang, K. J. Chromatogr. A, 2017, 1492, pp 89-97 (http://dx.doi.org/10.1016/j. chroma.2017.02.074).

77. Debrus, B.; Lebrun P.; Hubert, Ph.; Schofield, T.; Marini, R. D.; Rudazm S.; Boulanger, B.; Rozet, E.; Mbinze, J. K. LCGC Europe, 2013, 26, pp 370-377. Available from: http://www.chromatographyonline. $\mathrm{com} /$ new-method-quality-design-robust-optimization-liquid-chromatography?id=\&pagelD=1\&sk=\&da te $=$ [Accessed 20 October 2019].

78. Hubert, C.; Lebrun, P.; Houari, S.; Ziemons, E.; Rozet, E.; Hubert, Ph. J. Pharm. Biomed., 2014, 88, pp 401-409 (http://dx.doi.org/10.1016/j.jpba.2013.09.026).

79. Jain, A.; Beg, S.; Saini, S.; Sharma, T.; Katare, O. P.; Singh, B. J. Liq. Chromatogr. Relat. Technol., 2019, 42, pp 502-512 (https://doi.org/10.1080/10826076.2019.1626742).

80. Sharma, T.; Khurana, R. K.; Jain, A.; Katare, O. P.; Singh, B. Biomed. Chromatogr., 2018, 32, pp 1-15 (https://doi.org/10.1002/bmc.4169).

81. Trichta, E. V.; Geurink, L.; Backus, H.; Germano, M.; Somsen, G. W.; Griend, C. E. S. V. Talanta, 2017, 166, pp 8-14 (http://dx.doi.org/10.1016/j.talanta.2017.01.013).

82. Garg, L. K.; Sait, S. S.; Krishnamurthy, T.; Kumar, C. H. R. P. J. Liq. Chromatogr. Relat. Technol., 2015, 38 (6), pp 677-686 (https://doi.org/10.1080/10826076.2014.951766). 
83. Miloševic, N.; Vemic, A.; Čolovic, J.; Kostic, N.; Malenovic, A. Chromatographia, 2017, 80, pp 585-592 (https://doi.org/10.1007/s10337-017-3275-5).

84. Djuris, J.; Medarevic, D.; Krstic, M.; Djuric, Z.; Ibric, S. J. Pharm. Sci., 2013, 102, pp 1869-1882 (https://doi.org/10.1002/jps.23530).

85. Yao, H.; Vancoillie, J.; D’Hondt, M.; Wynendaele, E.; Bracke, N.; Spiegeleer, B. D. J. Pharm. Biomed., 2016, 117, pp 232-239.

86. Dormenval, C.; Lokras, A.; Cano-Garcia, G.; Wadhwa, A.; Thanki, K.; Rose, F.; Thakur, A.; Franzyk, H.; Foged, C. Pharm. Res., 2019, 36, pp 1-15 (https://doi.org/10.1007/s11095-019-2663-y).

87. Colobatiu, L.; Gavan, A.; Mocan, A.; Bogdan, C.; Mirel, S.; Tomuta, I. React. Funct. Polym., 2019, 138, pp 46-54 (https://doi.org/10.1016/j.reactfunctpolym.2019.02.013).

88. Herneisey, M.; Lambert, E.; Kachel, A.; Shychuck, E.; Drennen III, J. K.; Janjic, J. M. Molecules, 2019, 24, pp 1-20 (https://doi.org/10.3390/molecules24112066).

89. Wu, H.; Khan, M. A. J. Pharm. Sci., 2009, 98 (10), pp 2784-2798 (https://doi.org/10.1002/jps.21646).

90. Reid, G. L.; Cheng, G.; Fortin, D. T.; Harwood, J. W.; Morgado, J. E.; Wang, J.; Xue, G. J. Liq. Chromatogr. Relat. Technol., 2013, 36, pp 2612-2638 (https://doi.org/10.1080/10826076.2013.7654 57).

91. Agrawal, V. P.; Desai, S. S.; Jani, G. K. Eurasian J. Anal. Chem., 2016, 11 (2), pp 63-78 (https://doi. org/10.12973/ejac.2016.122a).

92. Basso, J.; Mendes, M.; Cova, T. F. G. G.; Sousa, J. J.; Pais, A. A. C. C.; Vitorino, C. Anal. Methods, 2018, 10, pp 5659-5671 (https://doi.org/10.1039/c8ay01695j).

93. Joshi, V. S.; Kumar, V.; Rathore, A. S. J. Chromatogr. A, 2017, 1491, pp 145-152 (http://dx.doi. org/10.1016/j.chroma.2017.02.058).

94. Kochling, J.; Wu, W.; Hua, Y.; Guan, Q.; Castaneda-Merced, J. J. Pharm. Biomed., 2016, 125, pp $130-$ 139 (http://dx.doi.org/10.1016/j.jpba.2016.03.031).

95. Pathak, M.; Chaudhary, N.; Rathore, A. S. J. Pharm. Biomed., 2014, 92, pp 119-126 (http://dx.doi. org/10.1016/j.jpba.2014.01.007).

96. Draheim, C.; Crécy, F.; Hansen, S.; Collnot, E. M.; Lehr, C. M. Pharm. Res., 2015, 32, pp 2609-2624 (https://doi.org/10.1007/s11095-015-1647-9).

97. Agarabi, C. D.; Schiel, J. E.; Lute, S. C.; Chavez, B. K.; Boyne, M. T.; Brorson, K. A.; Khan, M. A.; Read, E. K. J. Pharm. Sci., 2015, 104, pp 1919-1928 (https://doi.org/10.1002/jps.24420).

98. Kormány, R.; Tamás, K.; Guillarme, D.; Fekete, S. J. Pharm. Biomed. Anal., 2017, 146, pp 220-225 (http://dx.doi.org/10.1016/j.jpba.2017.08.032).

99. Hubert, C.; Hauari, S.; Rozet, E.; Lebrun, P.; Hubert, Ph. J. Chromatogr. A, 2015, 1395, pp 88-98 (http://dx.doi.org/10.1016/j.chroma.2015.03.059).

100. Ismail, R.; Sovány, T.; Gácsi, A.; Ambrus, R.; Katona, G.; Imre, N.; Csóka, I. Pharm. Res., 2019, 36, pp 1-16 (https://doi.org/10.1007/s11095-019-2620-9).

101. Bracke, N.; Barhdadi, S.; Wynendaele, E.; Gevaert, B.; D'Hondt, M.; Spiegeleer, B. Sens. Actuators B, 2015, 210, pp 103-112 (http://dx.doi.org/10.1016/j.snb.2014.12.092).

102. Yerlikaya, F.; Ozgen, A.; Vural, I.; Guven, O.; Karaagauglu, E.; Khan, M. A.; Capan, Y. J. Pharm. Sci., 2013, 102, pp 3748-3761 (https://doi.org/10.1002/jps.23686).

103. Girotra, P.; Singh, S. K.; Kumar, G. Int. J. Biol. Macromol., 2016, 85, pp 92-101 (http://dx.doi. org/10.1016/j.ijbiomac.2015.12.069).

104. Nagashima, H.; Watari, A.; Shinoda, Y.; Okamoto, H.; Takuma, S. J. Pharm. Sci., 2013, 102, pp 42744283 (https://doi.org/10.1002/jps.23744).

105. Paul, J.; Jensen, S.; Dukart, A.; Cornelissen, G. J. Chromatogr. A, 2014, 1366, pp 38-44 (http://dx.doi. org/10.1016/j.chroma.2014.09.029).

106. Panda, S. S.; Sharma, K.; Mohanty, B.; Bera, R. K. V. V.; Acharjya, S. K.; Sarwar, B. J. Liq. Chromatogr. Relat. Technol., 2017, 40 (19), pp 951-958 (https://doi.org/10.1080/10826076.2017.1387558). 
107. Debrus, B.; Lebrun, P.; Kindenge, J. M.; Lecomte, F.; Ceccato, A.; Caliaro, G.; Mbay, J. M. T.; Boulanger, B.; Marini, R. D.; Rozet, E.; Hubert, Ph. J. Chromatogr. A, 2011, 1218 (31), pp 5205-5215 (https://doi. org/10.1016/j.chroma.2011.05.102).

108. Patel, M.; Kothari, C. Biomed. Chromatogr., 2019, 33 (10), pp 1-10 (https://doi.org/10.1002/bmc.4607).

109. Mandenius, C. F.; Brundin, A. Biotechnol. Prog., 2008, 24 (6), pp 1191-1203 (https://doi.org/ 10.1002/ btpr.67).

110. Venkatesh, M. P.; Philip, A.; Gangadharappa, H. V. Int. J. Pharm. Sci. Res., 2019, 10 (3), pp 10951100 (http://dx.doi.org/10.13040/IJPSR.0975-8232.10(3).1095-00).

111. Bezerra, M. A.; Santos, Q. O.; Santos, A. G.; Novaes, C. G.; Ferreira, S. L. C.; Souza, V. S. Microchem. J., 2016, 124, pp 45-54 (http://dx.doi.org/10.1016/j.microc.2015.07.023).

112. Ferreira, S. L. C.; Bruns, R. E.; Ferreira, H. S.; Matos, G. D.; David, J. M.; Brandao, G. C.; da Silva, E. G. P.; Portugal, L. A.; dos Reis, P. S.; Souza, A. S., et al. Anal. Chim. Acta, 2007, 597 (2), pp 179-186 (http://doi.org/10.1016/j.aca.2007.07.011).

113. Pereira, F. M. V.; Pereira-Filho, E. R. Quím. Nova, 2018, 41 (9), pp 1061-1071 (http://dx.doi. org/10.21577/0100-4042.20170254).

114. Mokhtar, H. I.; Abdel-Salam, R. A.; Hadad, G. M. Chromatographia, 2015, 78, pp 457-466 (https://doi. org/10.1007/s10337-015-2858-2).

115. Schmidt, A. H.; Wess, C. J. Liquid. Chromatogr. Relat. Technol., 2014, 37 (18), pp 2653-2666 (https:// doi.org/10.1080/10826076.2013.853312).

116. Arai, H.; Suzuki, T.; Yada, S.; Kaseda, C.; Onuki, Y.; Takayama, K. Chem. Pharm. Bull., 2011, 59 (5), pp 608-617 (https://doi.org/10.1248/cpb.59.608).

117. Nistor, I.; Lebrun, P.; Ceccato, A.; Lecomte, F.; Slama, I.; Oprean, R.; Badarau, E.; Dufour, F.; Dossou, K. S. S.; Fillet, M., et al. J. Pharm. Biomed. Anal., 2013, 74, pp 273-283 (http://dx.doi.org/10.1016/j. jpba.2012.10.015).

118. Jambo, H.; Dispas, A.; Avohou, H. T.; André, S.; Hubert, C.; Lebrun, P.; Ziemons, E.; Hubert, P. J. Chromatogr. B, 2018, 1092, pp 332-342 (https://doi.org/10.1016/j.jchromb.2018.05.049).

119. Kurmi, M.; Kumar, S.; Singh, B.; Singh, S. J. Pharm. Biomed. Anal., 2014, 96, pp 135-143 (http:// dx.doi.org/10.1016/j.jpba.2014.03.035).

120. Maeda, J.; Suzuki, T.; Takayama, K. Chem. Pharm. Bull., 2012, 60 (9), pp 1155-1163 (https://doi. org/10.1248/cpb.c12-00340).

121. Mokhtar, H. I.; Abdel-Salam, R. A.; Hadad, G. M. J. Chromatogr. A., 2015, 1399, pp 32-44 (http:// dx.doi.org/10.1016/j.chroma.2015.04.038).

122. Taraji, M.; Haddad, P. R.; Amos, R. I. J.; Talebi, M.; Szucs, R.; Dolan, J. W.; Pohl, C. A. Anal. Chem., 2017, 89 (3), pp 1870-1878 (https://doi.org/10.1021/acs.analchem.6b04282).

123. Chhatre, S.; Farid, S. S.; Coffman, J.; Bird, P.; Newcombe, A. R.; Titchener-Hooker, N. J. J. Chem. Technol. Biotechnol., 2011, 86 (9), pp 1125-1129 (https://doi.org/10.1002/jctb.2628).

124. Saviano, A. M.; Francisco, F. L.; Ostronoff, C. S.; Lourenço, F. R. J. AOAC Int., 2015, 98 (5), pp 12671275 (https://doi.org/10.5740/jaoacint.15-074).

125. Kormány, R.; Molnár, I.; Fekete, J. J. Pharm. Biomed., 2017, 135, pp 8-15 (http://dx.doi.org/10.1016/j. jpba.2016.11.050).

126. Sun, X. T.; Tan, Q. J.; Wang, S. X.; Shan, J. F.; Jiang, J. L. Anal Methods, 2015, 7 (13), pp 5428-5435 (https://doi.org/10.1039/C5AY01000D).

127. Nadella, N. P.; Ratnakaram, V. N.; Srinivasu, N. J. Liq. Chromatogr. Relat. Technol., 2017, 40 (10), pp 517-527 (https://doi.org/10.1080/10826076.2017.1330211). 